\title{
Tombs of the Roman Period in Sector 26 of the High Necropolis Archaeological Site of Oxyrhynchus, El-Bahnasa
}

\author{
Esther PONS MELLADO
}

\begin{abstract}
The archaeological site of Oxyrhynchus (El-Bahnasa), the ancient city of Per-Medjed, is located $190 \mathrm{~km}$ south of Cairo. One of its most extensive and important areas is the so-called High Necropolis, where burials from the Saite Period to Christian-Byzantine times can be found. During 2008 season, the Archaeological Mission of Oxyrhynchus started working in the south-eastern section of this necropolis and found a Roman funerary complex. The tombs were built of regular limestone blocks, with vaulted ceilings, and had one or more funerary chambers decorated with paintings and reliefs on some of the walls. Inside, a large number of mummies and interesting funerary objects show the syncretism between Egyptian and Roman cultures.
\end{abstract}

El yacimiento arqueológico de Oxirrinco (El-Bahnasa), la antigua ciudad de Per-Medjed, está situada a $190 \mathrm{~km}$ al sur de El Cairo. Una de las zonas más grandes e importantes es la denominada Necrópolis Alta, que abarca un amplio marco cronológico que va desde el Periodo Saíta hasta la etapa Cristiano-Bizantina. En 2008, se comenzó a trabajar en una nueva zona situada al S.E. de dicha necropolis, en donde se descubrieron una serie de tumbas del period Romano construidas con bloques de piedra caliza, con techo abovedado y con una o más cámaras funerarias, algunas de ellas decoradas con pinturas y relieves. En su interior, había un gran número de momias y un interesante ajuar funerario que evidencian el sincretismo entre la cultura egipcia y romana.

Keywords: Oxyrhynchus, Roman tombs, mummies, reliefs, paintings, funerary objects.

Palabras clave: Oxirrinco, Tumbas romanas, momias, relieves, pinturas, objetos funerarios.

\section{The} archaeological site of Oxyrhynchus (El-Bahnasa), the ancient city of Per-Medjed, is located $190 \mathrm{~km}$ south of Cairo (fig. 1). It was the capital of the 19 nome of Upper Egypt and became a very important centre because of its geographical situation, on the banks of the Bar Yusuf and at the crossroad leading to the oases of the Western Desert, especially to Bahariya, a trading centre where many caravan routes converged.
The Archaeological Mission of the University of Barcelona, under the direction of Josep Padró i Parcerisa' ${ }^{1}$, has been working on the left bank of the Bar Yusuf since 1992. One of the most extensive and important areas of the site is the so-called High Necropolis, which is located upon a raised sector and has burials ranging from the Saite Period to Christian-Byzantine times ${ }^{2}$.

1 Now Emeritus Professor of the University of Barcelona.

2 Padró et alii, 2006.

\author{
TdE 7 (2016) - Páginas: 161-178 \\ Recepción: 15/10/2016 - Admisión: 02/11/2016 \\ Esther Pons Mellado - esther.pons@mecd.es \\ Departamento de Antigüedades Egipcias y del Próximo Oriente / Museo Arqueológico Nacional / Madrid / España
}




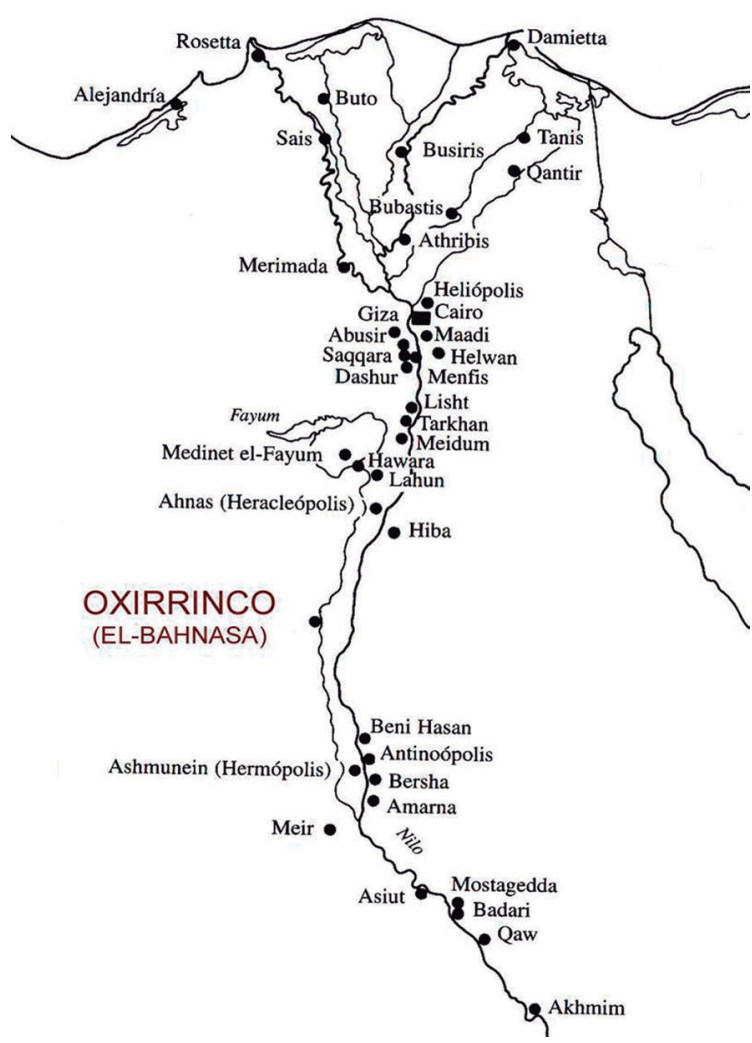

Figure 1. Archaeological Site of Oxyrhynchus.

One of the objectives of the 2008 season $^{3}$ was to work in a new sector to the southeast of this necropolis that was called Sector $26^{4}$. This new area comprises a Roman complex that, as far as can be ascertained, is composed of six tombs built of white limestone blocks $(25 / 40 \mathrm{~cm}$ in length and $15 / 25 \mathrm{~cm}$ in width) with vaulted ceilings, although in some cases the latter are incom- plete or totally lost. The tombs have one or more burial chambers and have yielded very interesting findings (fig. 2).

On the upper layers, several rooms built with mudbricks (both baked and unbaked) were identified. Of these structures, only the walls remain, although in one of them the lower part of the vaulted ceiling was still preserved. Inside room No. 1 were several individuals in supine position, with their heads orientated towards the west and their feet to the east, the hands resting on the pubic bone and with some pottery fragments and several coins as funerary objects; all of them are in a very bad condition. Although the study of the rooms is not yet finished, it remains possible that they were built to protect the stone underground tombs below, since they were contemporaneously reused. The material culture discovered, both inside and around the rooms, has allowed dating them to the Christian-Byzantine times. Under these structures of mudbricks, three tombs dating to the Roman Period have been found (No's 18, 19, and 20, fig. 3) ${ }^{5}$.

During the 2009 season $^{6}$, the mission decided to expand the excavation sector to the north, east, and west. Here, a further tomb was found in the north-eastern area, which was numbered 21. It bears similar architectural characteristics to the tombs explored during the previous season.

3 Padró et alii, 2008: 3-16; Padró et alii, 2010: 46-58.

4 The archeological works (2008-2014) were directed by Esther Pons Mellado. Excavation' team members: Hassan Amer (archaeologist), Marta Saura (archaeologist), José Javier Martínez (archaeologist), Annie Perraud (specialist in mummies), Bernat Burgaya (restorer), Antonio López (surveyor), and Eloy Algorri (architect).

5 Padró et alii, 2008: 4-6; Pons, 2012: 289-29, fig. 2-6.

6 The archaeological work in this sector was performed by: Hassan Amer (archaeologist), Anaïs Tillier (drawer), Annie Perraud (specialist in mummies), Bernat Burgaya (restorer), Antonio López (surveyor) and Eloy Algorri (architect). 


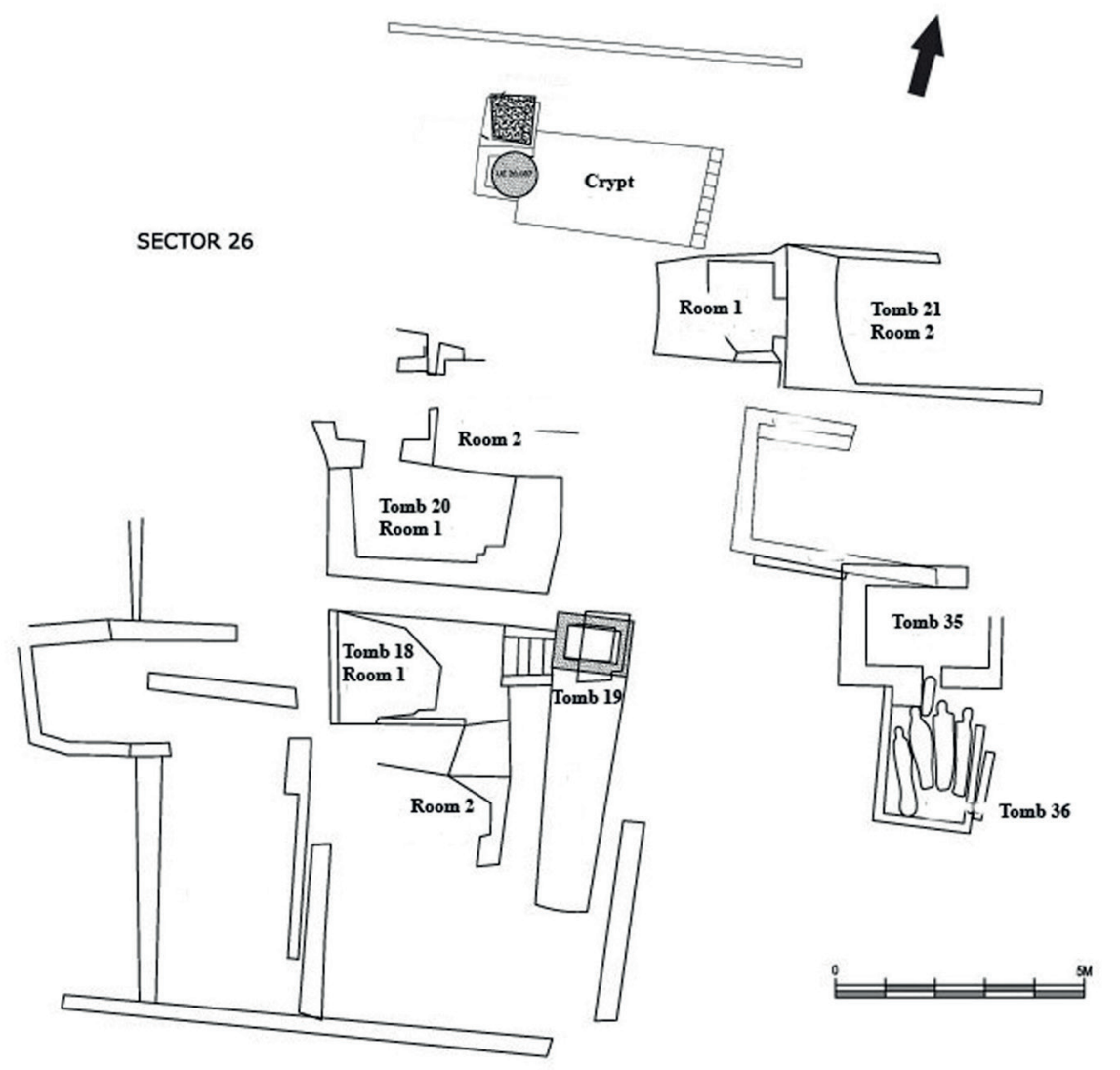

Figure 2. Topographic Map of Sector 26.

It was not until 2013 that the mission could restart ${ }^{7}$ the archaeological works in this sector. Unfortunately, only a few days could be devoted to the area, which resulted in the discovery of some remains of a new tomb (No. 35$)^{8}$. A part of the tasks carried out in $2014^{9}$ focused on Sector 26, above all in Tomb No. 35 , which had remained unexcavated during the previous season, and in Tomb No. 36 , a structure discovered that year ${ }^{10}$.

\section{Tomb No. 18}

Tomb No. 18 shows two parallel, rectangular funerary chambers, internally con-

7 The so-called Arab Spring, which took place in Egypt from 25th January 2011, interrupted archaeological works in the majority of the excavations in Egypt and especially in Middle Egypt. In 2012, the mission restarted work in Oxyrhynchus, but in that season the team concentrated on in the Roman necropolis in Sector $2 \mathrm{D}$.

8 The excavations in this sector were undertaken between March 8th-1oth, with only enough time to work in the upper layers of this tomb and the area around it.

9 The archaeological tasks were performed by Hassan Amer (archaeologist), Irene Ruidavest (archaeologist), Bibiana Agustí (anthropologist), Bernat Burgaya (restorer), and Antonio López (surveyor).

10 Padró et alii, 2014: 13-17. 


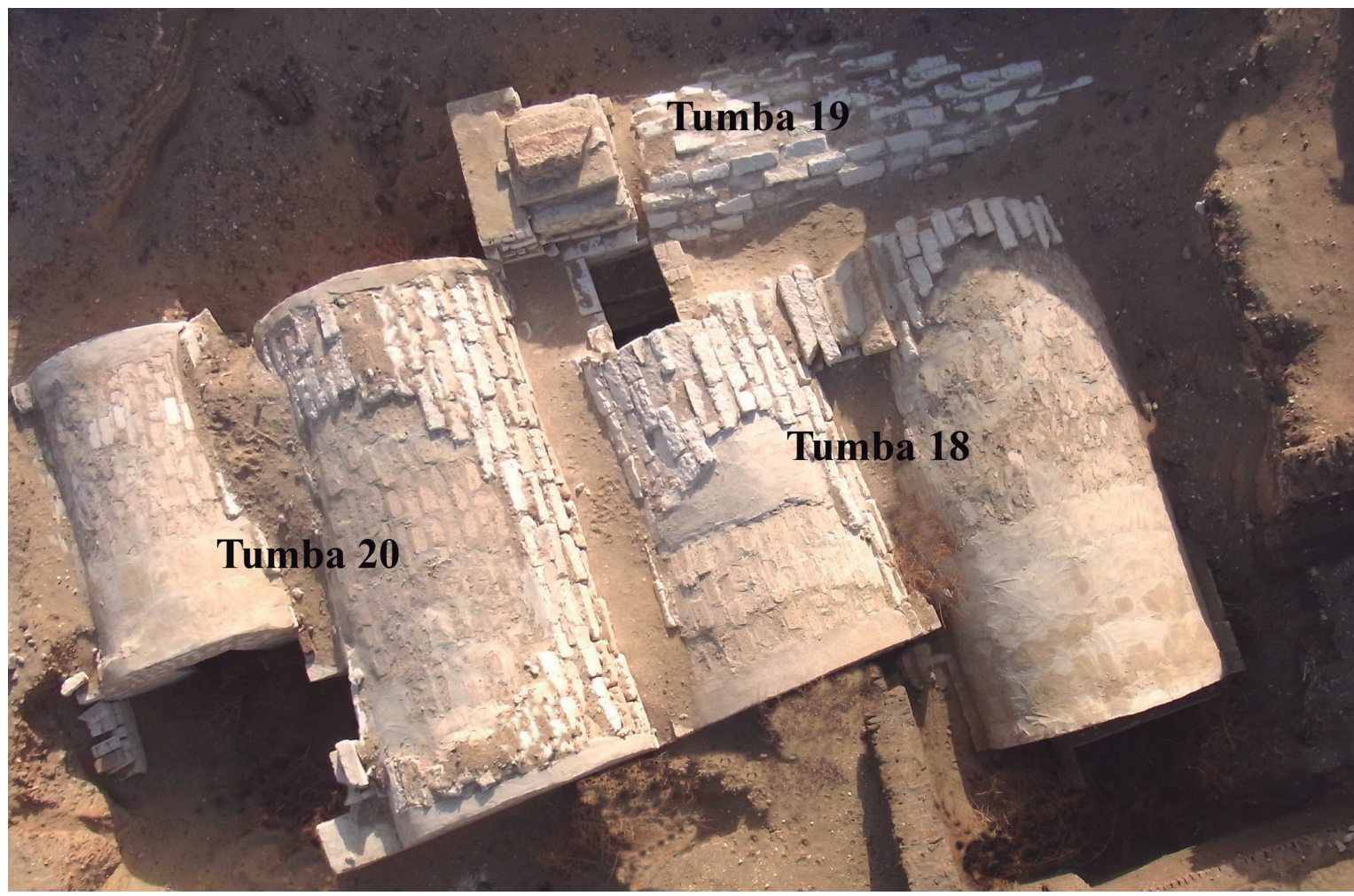

Figure 3. Aerial view of Sector 26. Tombs No. 18-20.

nected by a narrow passage $70 \mathrm{~cm}$ wide. Access to chamber 1 is from the east via a stairway consisting of five steps. Just outside the entrance there was an Egloff type amphora (from the third century AD), deposited as an offering ${ }^{11}$.

Room 1 (3.35 $\mathrm{m}$ in length, $2.65 \mathrm{~m}$ in width, and 2.30 in height) has preserved the eastern, western, and southern walls, as well as part of the northern wall and the ceiling. The west wall has two triangular hollows for some type of lighting device (for example, oil lamps) ${ }^{12}$, while the west wall and the ceiling still preserve the remains of painted decoration applied on a layer of plaster, although in some places the plaster has disappeared.

The west wall is decorated with a pair of offering scenes. The right one (fig. 4), the best preserved, shows the god Osiris enthroned, looking to the right and depicted mummiform, clad in a reddish shroud as a personification of power. He holds in his hands the symbols of power, the crook and the flail, and wearing a wesekh necklace. Unfortunately, the head and the crown (possibly an atef-crown with the two feathers and horns) are missing ${ }^{13}$.

11 Kelley, 1976: plates 97.32, 97.34, 99.5.

12 The southern wall of this room, next to the entrance of the narrow passage, had many black stains because of the use of lamps inside it.

13 The image of Osiris with this type of crown also appears in a relief in Tomb No. 2. 


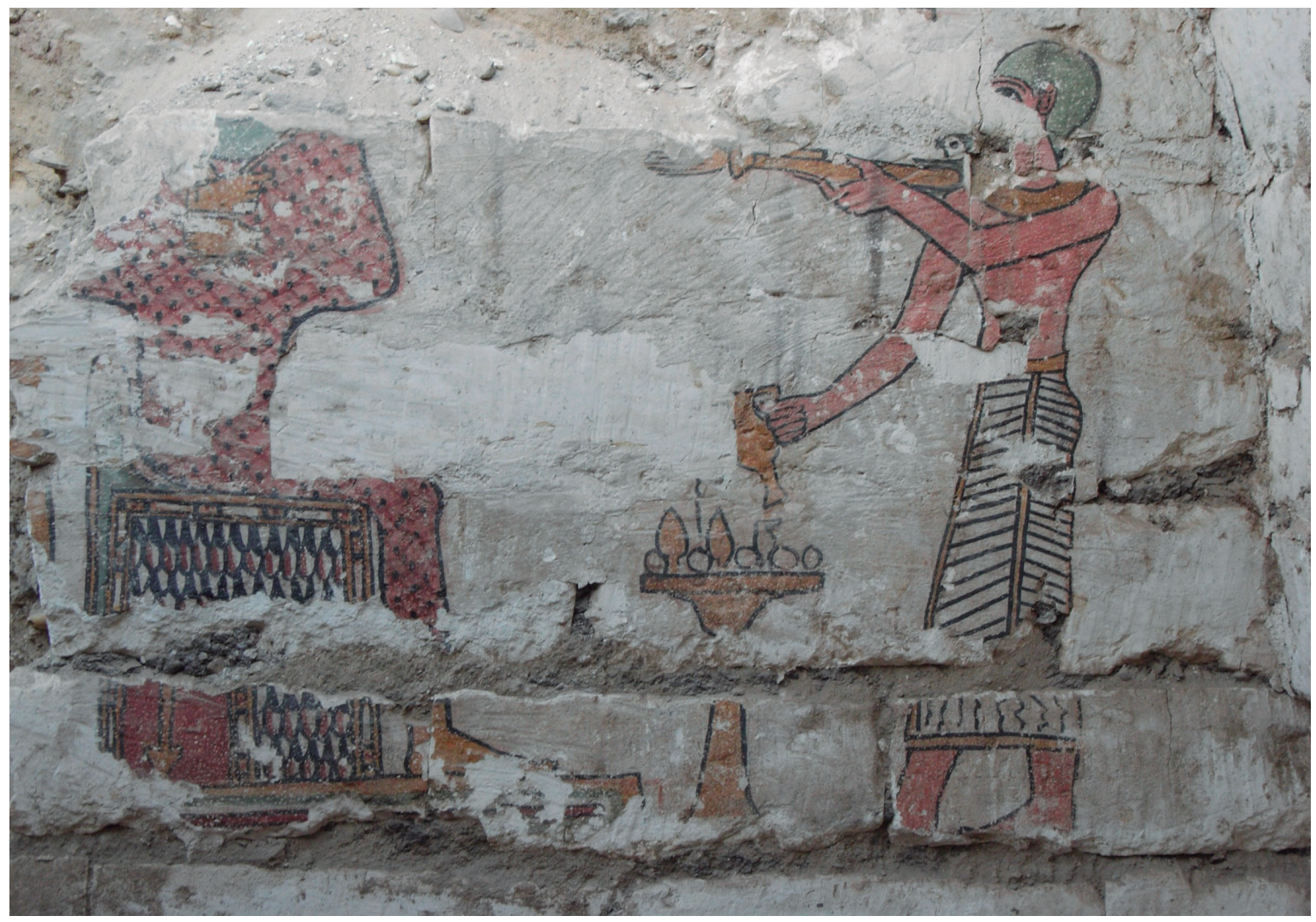

Figure 4. Offering scene of room 1. Tomb No. 18.

In front of Osiris there is a standing male figure, probably the owner of the tomb, dressed in an ankle-length pleated skirt and wearing a wesekh necklace and a tight helmet. He is holding in his right hand a libation jar; in his left hand, which rests on his right shoulder, he has a censer in the shape of an arm and open palm on which sits a cup, with a head of a falcon on the opposite side $^{14}$. Between these two figures, there is an offering table with food for the $k a$. In addition to both figures, the god Anubis appears to the right wearing a large necklace, and the goddesses Isis and Hathor to the left side ${ }^{15}$.

Unfortunately, the left scene is very badly damaged, and only the feet and part of the skirt of the male figure, who is looking to the right, have been preserved; the feet and the lower part of the throne of Osiris are also visible.

This offering scene has a very clear parallel on a stone sarcophagus in Tomb No 3, which can be dated to the Roman Period and is located in this same necropolis, although in this case there is no pair

14 The Pelizaeus Museum (Hildesheim) has a very similar censer made of bronze, but the cup has the shape of an oval cartouche and in front of it there is a kneeling priest. Eggebrecht, 1984: 252.

15 Pons, 2012: 295, fig. 5; Erroux-Morfin, 2014: 210-211, fig. 19.3, 19.4, 19.6; Burgaya and Xarrié, 2014: 213215; Pons, 2014: 287-289. 


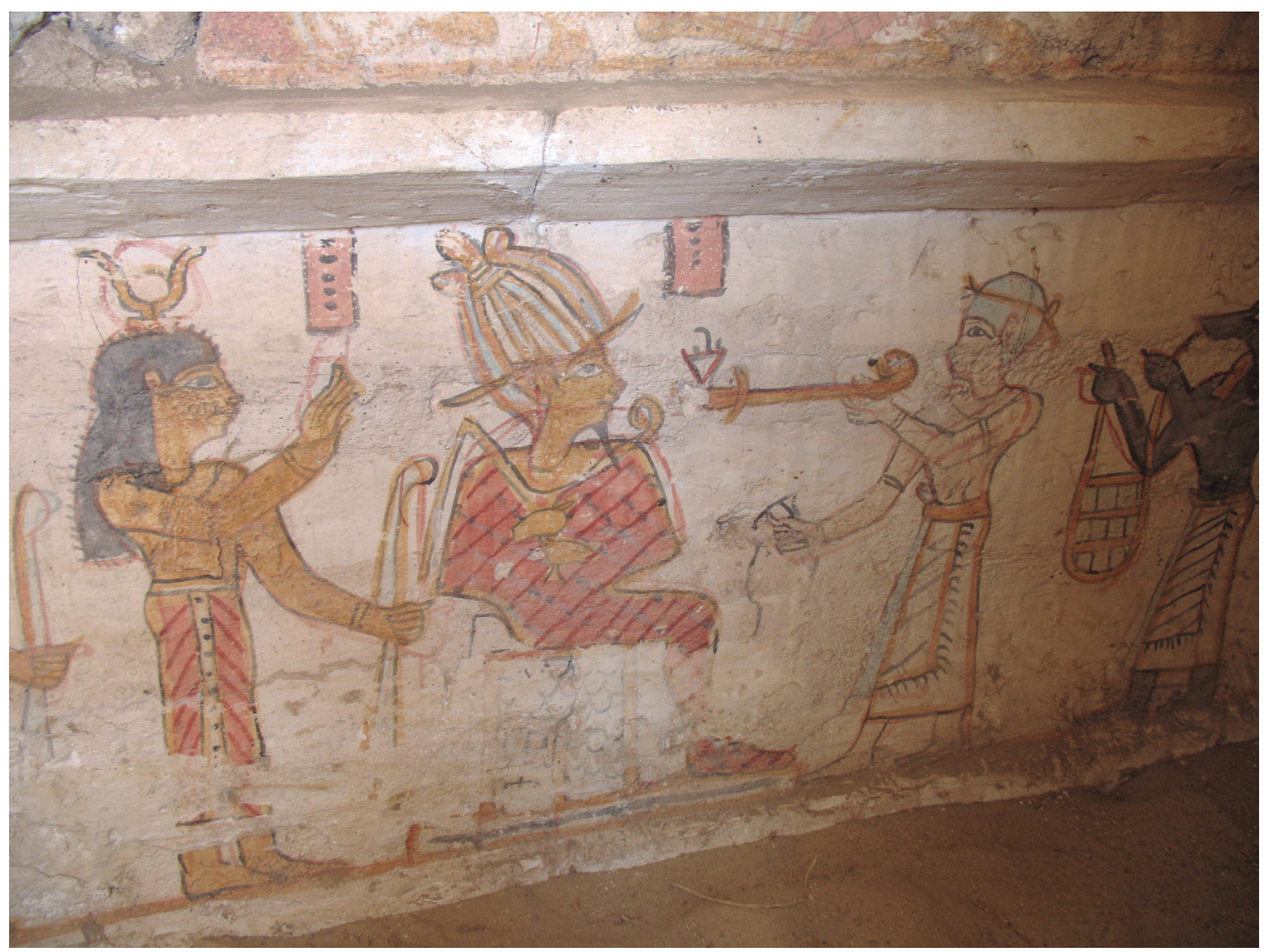

Figure 5. Offering scene. Tomb No. 3.

of scenes and the pictorial style is simpler (fig. 5$)^{16}$.

The vaulted ceiling is decorated with the image of the sky-goddess Nut (stretched out the east-west axis) ${ }^{17}$, whose body symbolised the vault of the sky. Regrettably only half of her the body has been preserved, including her feet (fig. 6). She is naked with her arms outstretched forwards, with a large belly imitating the sun disk, and the god Khepri in the shape of a winged scarab emerging from her uterus at dawn, as an image of regeneration and resurrection.

The goddess Nut is flanked on both sides by two long friezes in the form of different coloured waves: on one side black and green, symbolising fertility and the first act of creation, and on the other yellow and red, symbolising divinity and power.

The room had been completely looted, and no funerary objects remain, although during the cleaning process many painted

16 Tomb No. 3 is located in Sector $2 \mathrm{D}$ and was found in 1984 by the Egyptian Archaeological Mission under the direction of M. Hamza.

17 The image of the goddess Nut is commonly attested from the New Kingdom onwards, both on the ceilings of tombs and temples as well as on the underside of coffins and sarcophagi. 
fragments of limestone -both from the western wall and the ceiling- were found. One of the most interesting fragments bears the representation of an Oxyrhynchus fish, the sacred symbol of the city, which probably decorated the upper part of the offering scene on the western wall (fig. 7$)^{18}$. Another one is a part of the hand of Nut holding the sun disk, which she swallows at dusk. Vertebrae and bones of an Oxyrhynchus fish ${ }^{19}$ were also found near the southern wall.

Room No 2. (4.22 m long, $2.44 \mathrm{~m}$ wide, and $2.00 \mathrm{~m}$ high) was in a very bad condition and only the eastern wall, part of the northern and southern walls, and the lower part of the vaulted ceiling were preserved.

During the cleaning work, clay dish, many fragments of pottery, lamps, mudbricks, some bronze coins of the fourth to the sixth centuries $\mathrm{AD}$ (attesting to the reuse of the funerary structure), and the upper part of a stela with the image of a winged sun disk with uraeus, were found amongst the debris.

Almost at floor level, two fragments of limestone slabs were discovered. They covered a sarcophagus box of the same material, but were not part of the original lid and clearly belonged to two different objects ${ }^{20}$. The largest slab had a Greek inscription on the upper right with the name "De Policeudes".

Inside the sarcophagus there was a mummified male individual, wrapped in band-

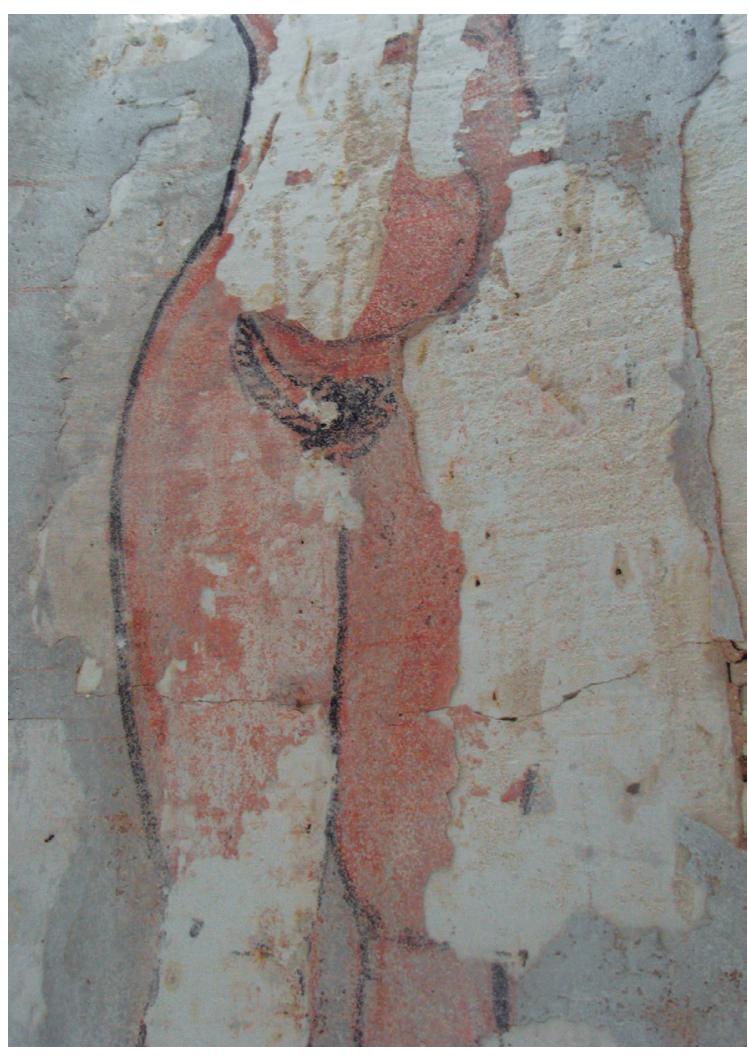

Figure. 6 Goddess Nut. Tomb No. 18.

ages of linen and in a very poor state of preservation. He was lying in a supine position, aligned in an east-west direction, and with his hands on the pubic bone. The head had been separated from the body and placed on the chest. No objects belonging to a funerary assemblage were found ${ }^{21}$ (fig. 8).

18 Pons, 2014: 289, fig. 24.2. On the cartonnage of one of the mummies found inside Tomb No. 11 appears the image of an Oxyrhynchus fish in front of a Lepidotus fish. In another cartonnage discovered in Tomb No. 12, only an Oxyrhynchus fish can be seen because the other fish has been lost. See Padró et alii, 2009a: 8-11.

19 A study of the bones was carried out in 2013 by Win van Neer, Archaeozoologist at the Royal Belgian Institute of Natural Sciences (Brussels, Belgium). University of Leuven, Laboratory of Biodiversity and Evolutionary Genomics.

20 Measurements of the sarcophagus: $199 \mathrm{~cm}$ in length, $57.7 \mathrm{~cm}$ maximum in width, $38.5 \mathrm{~cm}$ minimum in width and $39.5 \mathrm{~cm}$ in height.

21 This individual was burnt as a result of the process of mummification and all the bones from the waist to the feet were shattered. 


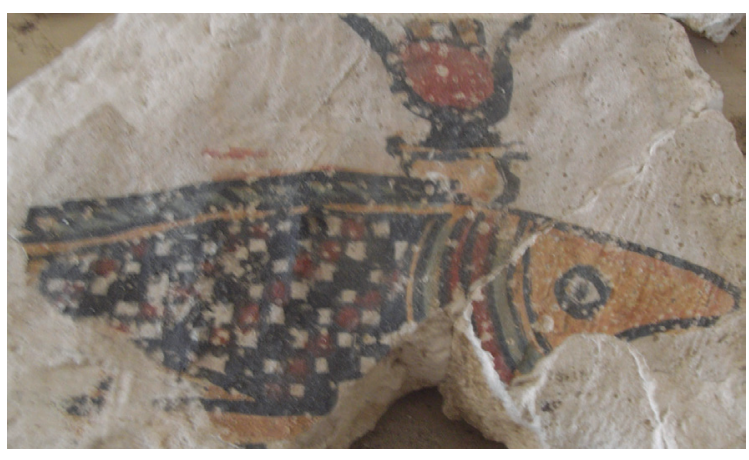

Figure 7. Image of oxyrhynchus fish. Room 1. Tomb No. 18.

\section{Tomb No. 19}

Tomb No. 19 (5.20 $\mathrm{m}$ in length, $2.50 \mathrm{~m}$ in width, and $2.60 \mathrm{~m}$ in height) is located to the east of Tomb No. 18. It is complete, intact, and with a single burial chamber that has the entrance from the north through a limestone shaft $(3.10 \mathrm{~m}$ in depth and $60 \mathrm{~cm}$ diameter) ${ }^{22}$.

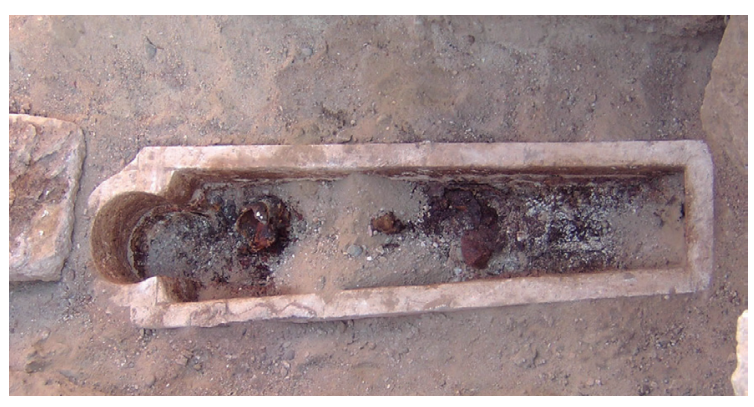

Figure 8. Sarcophagus. Room 2. Tomb No. 18.
Inside the tomb there was a large number of mummies piled on top of each other, both adults and children, all lying in a northsouth orientation, generally with the head towards the north. Only the mummy located in the entrance of the funerary chamber had an east-west orientation, with the head towards the west (fig. 9) 23. $^{23}$

All the mummies were bandaged in cloths decorated with a diamond design very typical of the Roman Period ${ }^{24}$, and in some cases the cartonnages had a polychrome painted decoration with Egyptian themes of both anthropomorphic (gods and goddesses, male and female figures) and zoomorphic types (above all sphinxes) (fig. 10).

Unfortunately, owing to both the large quantity of mummies and the impossibility of removing them from the burial chamber because of the difficult access ${ }^{25}$, the decision to close this chamber was taken. It is hoped that in the future the mission will have the necessary means to be able to study them in the appropriate way. Nevertheless, it was possible to see that, in general, the mummies were in a bad condition and that parts of the bandages had fallen off, especially in the mummies that were in the upper layers.

It is unknown whether these individuals were originally accompanied by funerary objects or not. However, it was possible to discern some fragments of a limestone sarcophagus between

22 This shaft is connected with the funerary chamber and it seems that it was built after the mummies were introduced inside the room.

23 There are around 80-9o mummies, but this number is a rough estimation because the bodies are placed in six layers and cover almost all the funerary chamber. Moreover, it has not yet been possible to get inside the room.

24 For parallels of this type of bandage, see: Walker and Bierbrier, 1997: 78-79, fig. 50.

25 The only access to this chamber is through the shaft, and owing to the narrowness of the latter, any plan to extract them entailed a high risk of damaging the mummies. In addition, at present there is currently a lack of space to store and conserve them in a good condition. However, it is hoped to prepare a special research project for this interesting find. 


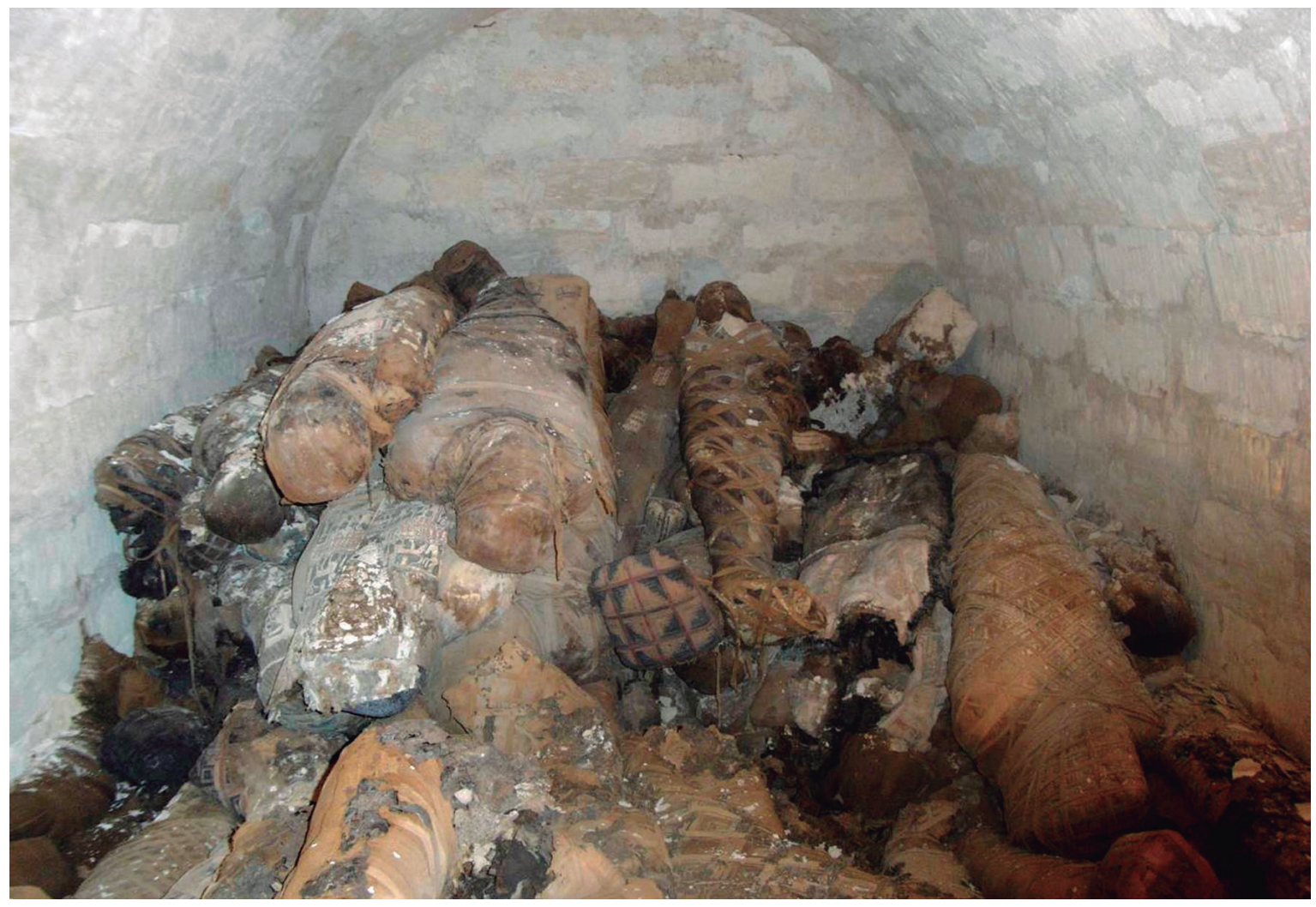

Figure 9. Mummies piled up on top of each other. Tomb No. 19.

the mummies, and the corpse that was in the entrance had a red clay bowl with the remains of mummified brains next to his head ${ }^{26}$.

On the outer side of the southern wall a pit was found (105 $\mathrm{cm}$ maximum length, $90 \mathrm{~cm}$ minimum width, and $135 \mathrm{~cm}$ in depth) and inside there was a foundation deposit with 15 pots and Egloff type amphorae, some of them broken, which are very similar to the amphora found at the entrance of Tomb No. 18 .

So far, it cannot be said when this group of mummies were placed inside the chamber, nor why the authority in charge of the necropolis decided to keep them here. It is quite possible that this room was a kind of secret chamber, conceived as a protection of the mummies to avoid their loss in case of destruction of the Roman necropolis in difficult times for the city of Oxyrhynchus.

\section{Tomb No. 20}

Tomb No. $2 \mathrm{O}^{27}$ is located to the north of Tomb No. 18. It has the entrance from the east and consists of two burial chambers and

26 The study of this mummy and the substance inside the bowl has been undertaken by A. Perraud. She has also studied two mummies (a man and a woman) that were located near this individual.

27 A Christian crypt was found (3.90 $\mathrm{m}$ in length, $1.90 \mathrm{~m}$ in height, and $1.50 \mathrm{~m}$ in width) to the west of this tomb. It was built of mudbricks and contained a total of 34 individuals and a green conical shaped bottle of glass. The anthropological study of this crypt was done by B. Agustí in 2013. Padró et alii, 2013: 12-13. 
a small exterior hall that connects the two rooms. It was covered with sand and is in quite poor condition.

Of the funerary room Nr. 2 and the hall, only a part of the lower section of their walls is preserved, and after taking out all the sand it was shown to have been completely empty. Room Nr. 1, bigger than the other room, only preserves its north and south walls.

The tomb had been reused in Christian times to bury ten individuals (only two of which were women), laid in an east-west orientation, with the head to the west and the hands in some cases on the pubic bone, and in other cases with one hand on the pubic bone and the other one next to the external side of the femur ${ }^{28}$. Some of the individuals had the remains of wooden coffins, but none of them had any funerary objects.

\section{Tomb No. 21}

Tomb No. 21 shows similar architectural characteristics to the tombs found in the previous season. It had the entrance from the east but had only one burial chamber and a small chapel. A great part of the vaulted ceiling and the walls were missing ${ }^{29}$.

The chamber was covered with brown debris and had been reused to bury individuals in the Christian era, but in general these corpses were in a very bad condition, all very mixed; for that reason, it has only been possible to clearly identify two of them, one child and a man between 40 and 50 years old $^{30}$. Moreover, some objects of the same

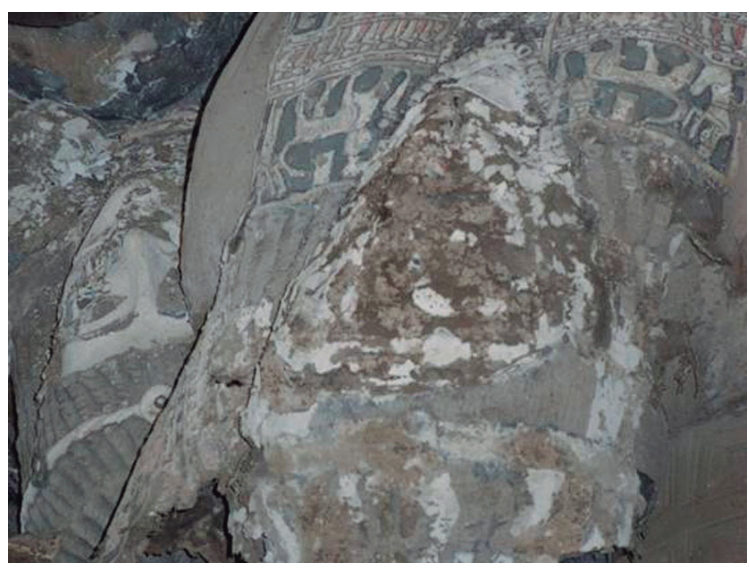

Figure 10. Cartonnages. Tomb No. 19.

period were discovered, among them four interesting small baskets of clay, each one with a handle and decoration of a lotus flower in relief on the base.

On the northern wall, several graffiti can also be distinguished: the image of a Horus-falcon and part of a second head of a Horus-falcon, a ship, and a fish.

The western wall, with an access door to the chapel, has painted decoration on either side of the door. The content is similar on both sides, but in a poor condition. The image on the right, which is better preserved, shows a male individual. He is walking and looking towards the door, and is dressed in a short skirt. In front of him there is a painted door and two apotropaic snakes (fig. 11).

The chapel has a relief decoration representing an offering scene on the western wall $3^{11}$ (fig. 12). In the centre of the scene the god Osiris, mummiform, appears enthroned and looking towards the right. He wears the atef-crown and holds the crook and flail

28 The bodies found were between 18 and 60 years old. Agustí, 2012: 19-21.

29 Padró et alii, 2009: 3-16. Padró, 2009: 36-38.

30 The bodies found were between 18 and 60 years old. Agustí, 2012: 19-21.

$3^{1}$ This is the only decoration in relief that the Archaeological Mission has found inside a tomb until now. 
across his chest. The image preserves traces of gold leaf on the face and the crown.

In front of him stands a worshipper offering gifts, looking towards the left. He wears an ankle-length tunic, his left arm extended close to his body, while in his right hand he holds a bag that he presents to Osiris.

The goddess Isis, standing and looking towards the right, is depicted on the left of Osiris, dressed in a tight ankle-length tunic. Her arms are raised as if motioning. Upon her head, the crown of the uraeus, and the tripartite wig can only be vaguely distinguished ${ }^{32}$.

One thing that strikes any observer is that the upper part of this scene is of much poorer quality than the lower part, as if the relief was done by two different artists.

The ceiling has some remains of painted decoration: one eye in black and traces of two arms and hands executed in a pinkish colour. This drawing is possibly part of an image of the goddess Nut, since in this period it was customary to depict this deity on the ceilings of the tombs, as in Tomb No. 18 (described above).

The northern and southern walls also have painted decoration, albeit in a very deteriorated state. A large part of the walls is covered with salts in the shape of roses, and because of this both the paint and the limestone blocks of the tomb are in a bad condition.

On the northern wall there are two figures looking and walking towards the exit door of the chapel. The first one is a male figure painted in blue, white, and greenish-blue/ turquoise, with a voluminous green hairstyle, dressed in a short yellow tunic, and holding in his right hand a sceptre of the same colour. The second one has a human body and the head of a jackal and represents the god Anubis. He is painted blue and outlined in black.

The southern wall also bears two figures looking and walking in the direction of the door. The first image is the god Thoth, with the head of an ibis and a human body, dressed in a skirt. He is painted in green and outlined in black. He is standing holding a writing tablet and a quill pen in his hands. His headdress in the form of the atef-crown with ram's horns can vaguely be distinguished. Behind him appears a badly damaged female figure, perhaps representing the goddess Isis with the tit-knot.

\section{Tomb No. 35}

Tomb No. 35 is very similar to the other tombs discussed so far; in other words, it was built of limestone blocks, has a vaulted ceiling, and was reinforced during the Christian era with five rows of mudbricks on the upper part of the western wall. The entrance was located in the east, while part of the northern wall is missing and with the southern wall it is possible to see the lower part of the vaulted ceiling.

In the upper layers of the stratigraphic deposits the following items were discovered: one complete bowl of red clay, one small basket with a lotus flower decoration on the base -of similar characteristics to the basket found in the 2008 season, a lamp with a very schematic decoration of a frog, many fragments of pottery, a mummified individual in a very bad condition, the remains of a mummified falcon with the wings perfectly bent and one of its claws still in place, as well as the remains of a kitten33.

32 Pons, 2014: 290-292, fig. 24.3, 24.4.

33 The male individual and the cat were studied by the anthropologist B. Agustí. 


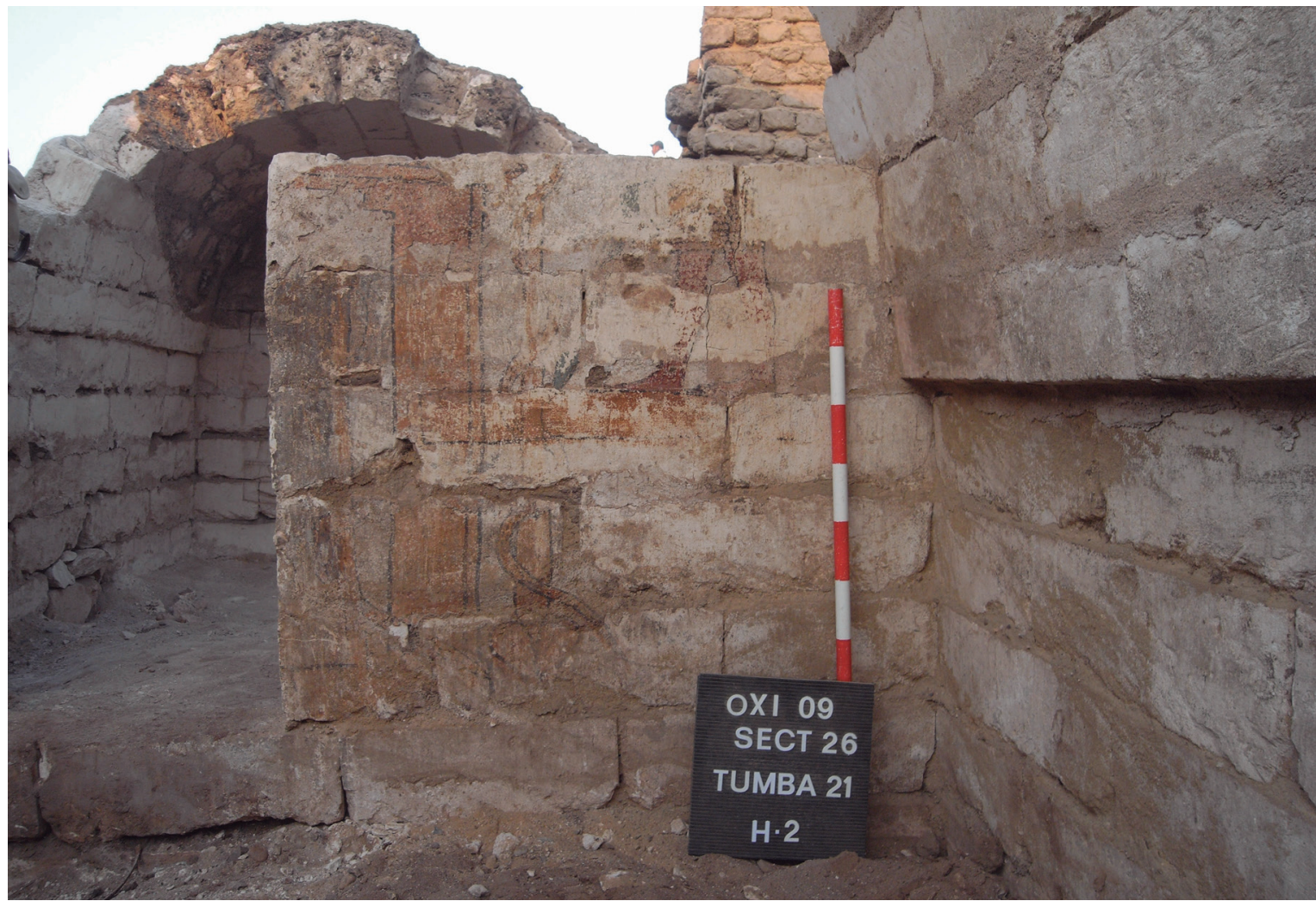

Figure 11. Painted decoration. Tomb No. 21

Tomb No. 35 (2.80 $\mathrm{m}$ in length, $1.92 \mathrm{~m}$ in height, and $1.98 \mathrm{~m}$ in width) has only one funerary chamber. It had been completely looted and was covered with earth.

Both inside and outside the tomb several mummified individuals (adults and children) of the Roman Period were discovered, all in a very bad condition 34 . None of them were in situ. The mummies were bandaged with many strips of linen on which, in some cases, it was possible to distinguish the typical diamond design of the Roman Period ${ }^{35}$. Only one bandage that covered part of the chest of one of the mummies has traces of a Greek inscription ${ }^{36}$. There were no funerary objects discovered.

Inside the tomb, three adults, three children, one mummified baby, and one mummified head were found ${ }^{37}$. Only one could

34 The mummies are now in the store of the mission and are being studied by A. Perraud.

35 Walker and Bierbrier, 1997: 78-79, plate 50; Corcoran, 1995: plate 1.11.

36 The mummy has been studied by I. Ruidavest.

37 No. 26207: $1.66 \mathrm{~m}$ in length. Orientation north-south, head to the south; No. 26208: 1.63 m in length. Orientation north-south, head to the south; No. 26210: $1.19 \mathrm{~m}$ in length. Orientation west-east, head to the north-east; No. 26212: $84 \mathrm{~cm}$ in length. Orientation north-south, head to the north; No. 26215: 1.58 $\mathrm{m}$ in length. Orientation north-south, head to the south; No. 26216 (packet of a mummified baby): 28 $\mathrm{m}$ in length; No. 26217: $69 \mathrm{~cm}$ in length. Orientation north-south, head to the north; No. 26218 (head): $24 \mathrm{~cm}$ in length. Mummies 26212 and 26218 have been studied by B. Agustí. 


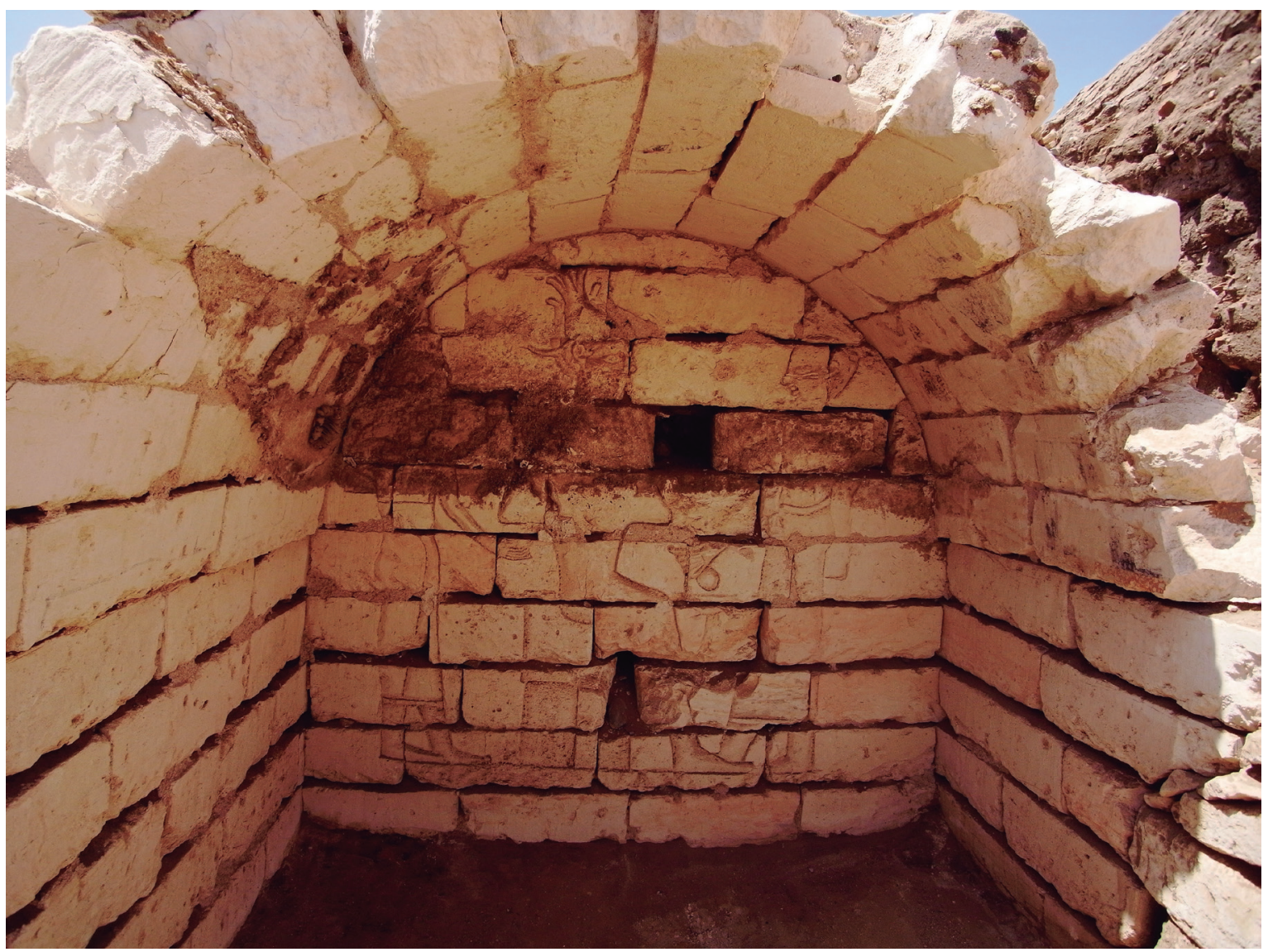

Figure 12. Relief decoration. Tomb No. 21.

be identified as a female. Our attention was struck by one mummy of a child, whose head lay inside the tomb next to the southern wall while its body was found outside this tomb and inside Tomb No. 36 (fig. $13)^{38}$. Another four mummified individuals near the exterior face of the southern wall were also discovered, three of them belonging to children 39 . All of them were placed lying east-west, with the head to the west.

During cleaning, some fragments of pottery and of some lamps with a geometric or schematic frog design, typical of Christian times, and a wooden Hathoric crown ${ }^{4}$ were found amongst the debris that covered the tomb.

It could be seen that the vaulted ceiling and the upper rows of the walls had been

38 No. 26209: $55 \mathrm{~cm}$ in length. Orientation north-south, head to the north.

39 No. 26203 (mummy with Greek inscription): $1.66 \mathrm{~m}$ in length. Orientation west-east, head to the west; No. 26213: $90 \mathrm{~cm}$ in length. Orientation west-east, head to the east; No. 26214: $78 \mathrm{~cm}$ in length. Orientation west-east, head to the east; No. $26221: 61 \mathrm{~cm}$ in length. Orientation west-east, head to the west; No. 26224: $1.49 \mathrm{~m}$ in length. Orientation west-east, head to the west.

40 During the 2013 season, a wooden Hathoric crown very similar but bigger, was found in the area of the offering fish Oxyrhynchus (Sector 32). 
rebuilt with mudbricks during the Christian era, and that the southern wall had undergone three different phases of construction: in the first two, limestone blocks were used, while in the third, mudbricks.

In the first phase, the entrance of the tomb was located in the southern wall and the limestone blocks were well aligned and joined by mortar, while in the second, not only was this entrance closed and a new entrance opened in the eastern wall, but the construction was also much less carefully done. The area north-east of the tomb was almost completely missing.

Tomb No. 36

Tomb No. 36 has also only one burial chamber and is perpendicular to Tomb No. 35; both tombs having one wall in common (the southern wall of Tomb 35 is the northern one of Tomb 36).

The tomb only preserves two rows of limestone blocks belonging to the eastern, western, and southern walls, but it is very interesting to highlight that in order to construct the tomb it was necessary to cut down into the geological level, at least in the west and south-west area.

Inside the tomb, in addition to the body of the child mentioned in Tomb No. 35, four mummified adults, in situ, were placed in a north-south position, with the heads towards the north ${ }^{41}$ and wrapped in several layers of linen were discovered. Thanks to the poor condition of the bandages, it is possible to see part of the mummified bodies and to confirm that they attest to a bad manufacturing process of mummification, typical during the Roman Period in the area of Oxyrhynchus ${ }^{42}$ (fig. 14).

The study of the bandages reveals that the thinnest and highest quality layers of linen are the first ones that were used to cover the bodies of the individuals. Around each neck there is a kind of scarf formed where the different layers of linen meet. The feet are bandaged in a kind of box of cartonnage with the typical diamond design. None of the mummies had funerary objects.

In the upper layers of both tombs, the following items were discovered: two plates of reddish clay, two lamps with schematic decoration of a frog, one tri-lobed bronze arrowhead in a very good condition -which is the only discovered example in the archaeological site of Oxyrhynchus, fragments of pottery and lamps, and several bronze coins that can not be identified owing to their poor condition.

One limestone stela was also found 43 . It bore a relief at the top with the image of a headless male figure dressed in a toga, with two fingers of the right hand on the left side of the toga and holding the "crown or garland of justification" in his left hand, as a confirmation or recognition that he has reached the afterlife ${ }^{44}$.

Some of its original paint has been preserved: some pink on the hands, as well as

41 No. 26239: 1.70 m in length; No. 26240: 1.6o m in length; No. 26241: 1.74 m in length; No. 26241: 1,75 $\mathrm{m}$ in length.

42 The mission did not excavate in this area during the 2015 season, but A. Perraud studied the two male individuals located to the east and the west of the room. Both had the hands placed on the pubic bones.

43 Measurements: $96 \mathrm{~cm}$ in length and $34 \mathrm{~cm}$ in width.

44 In some of the Fayum portraits the male individuals appear with the garland of justification. See Walker and Bierbrier, 1997: 126-127, plate 94; 146-147, plate 107. 


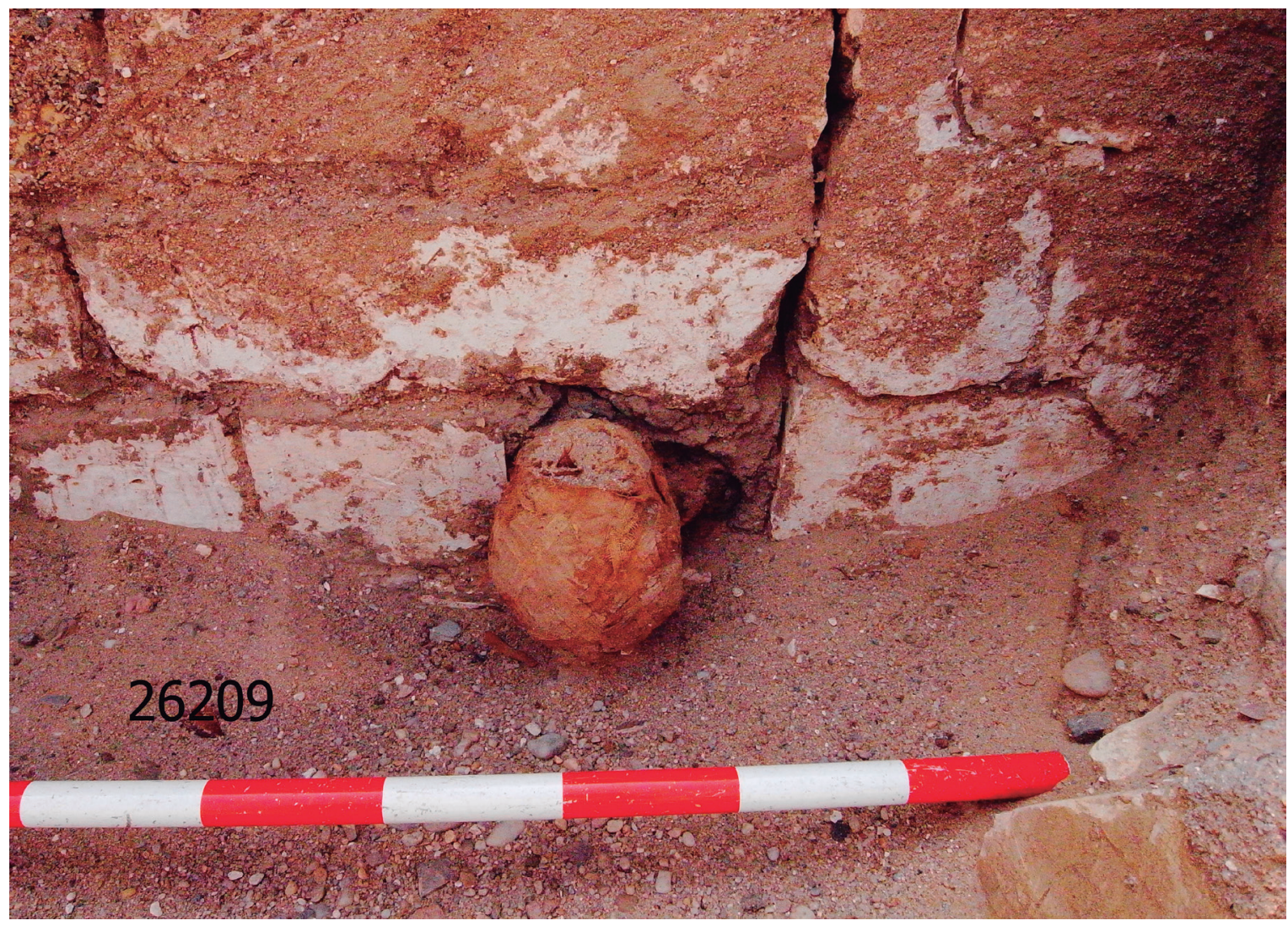

Figure 13. Child with the head inside Tomb No. 35 and the body inside Tomb No. 36.

floral motives in orange, red, and green colour in the lower part of the stela, and traces of a Roman inscription in a brown colour on the left side (fig. 15).

\section{Conclusions}

As a result of studying this group of tombs dating to Roman times, and leaving aside their later reuse in the Christian era, it has been possible to come to some very interesting conclusions.

The conquest of Egypt by Rome inaugurated a period of change and, in some cases, turmoil, which brought about a new different society and which affected all aspects of Egyptian life to a considerable degree, especially its funerary customs. While many of the customs of the inhabitants of the country of the Nile were transformed, Egypt succeeded in maintaining its traditions.

The process of mummification was not abandoned and the Egyptian funerary practices continued throughout these new times. In the case of the archaeological site of Oxyrhynchus, poor craftsmanship in the embalming process becomes evident, either because the necessary span of time to perform a correct mummification were not respected or because the material used was not appropriate for it. The result is that the individuals who were mummified during this period normally appear in a very bad condition. 


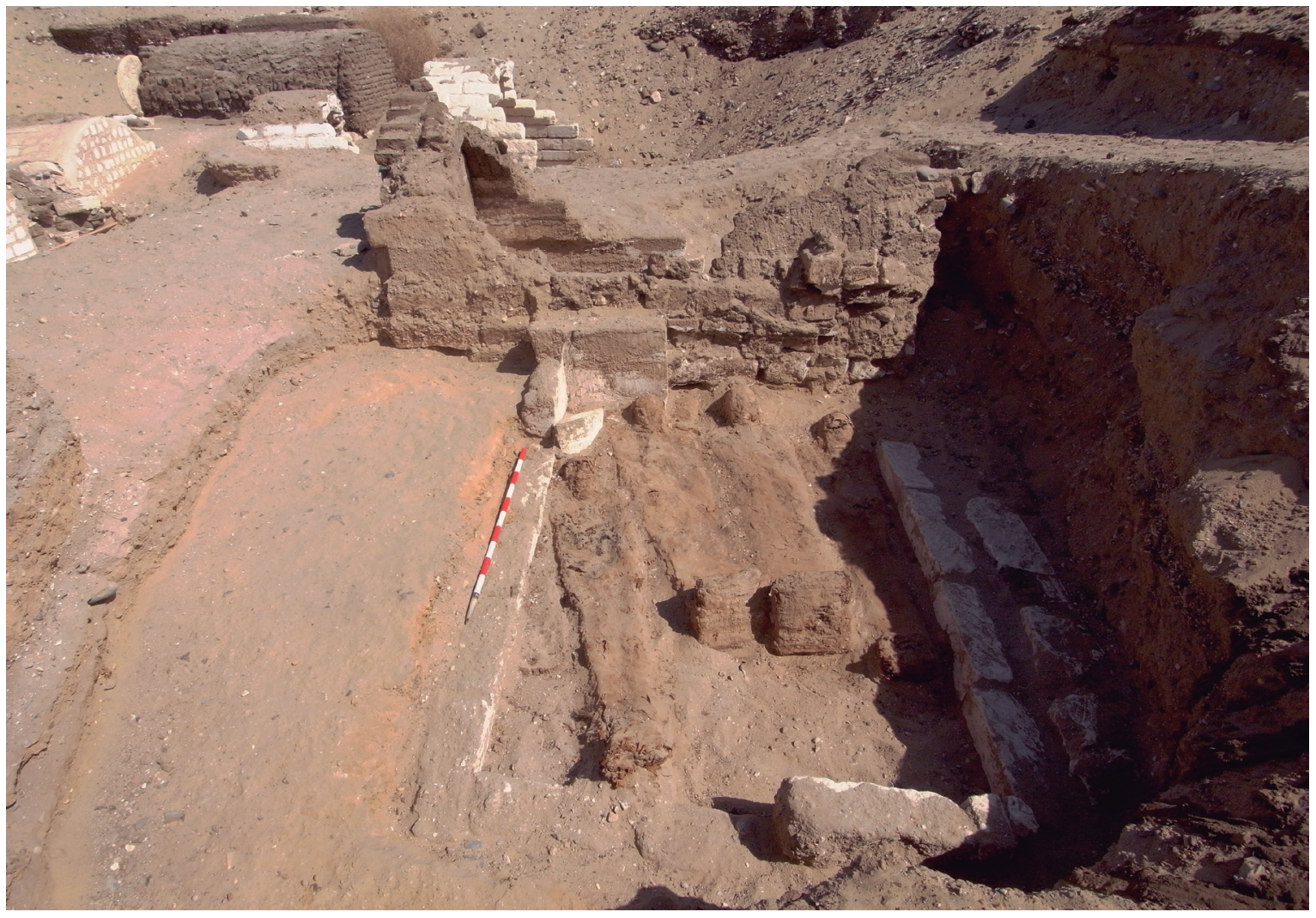

Figure 14. Mummies inside Tomb No. 36

The linen bandages that cover the bodies have a diamond design very characteristic of the Roman world in Egypt, and even the feet are also bandaged in a kind of rectangular box as if it were a cartonnage.

The decoration of some cartonnages that were found in Tomb 19 shows characteristics of both cultures. The faces, which tend to be realistic rather than idealistic, and the way of representing the hair locks, are both typical of the Roman era, but the griffins, deities (Isis), and uraei have undoubtedly been assimilated from Egyptian iconography.

There is also an important change in the funerary and religious objects that accompanied the deceased. Although it is true that there are no pieces associated specifically to any particular individual, the lamps and different pottery objects, above all bowls and plates, or fragments thereof, which appeared both inside and outside the tombs, indicate a new way of understanding the funerary world and the slow disappearance of the typical Egyptian objects such as shabtis or canopic jars.

The pictorial decoration and the reliefs on the walls of Tombs 18 and 21 show that Egyptian religion and its deities continue to be part of the inhabitants' concept of the afterlife in Egypt. Witness to this trend is the images of Isis and Osiris enthroned in front of a man praying, who is probably the owner of the tomb.

It is possible that the people that were buried in this Roman necropolis did not belong to a very high social class given the characteristics of the tombs. Knowing who they were or what kind of funerary objects 


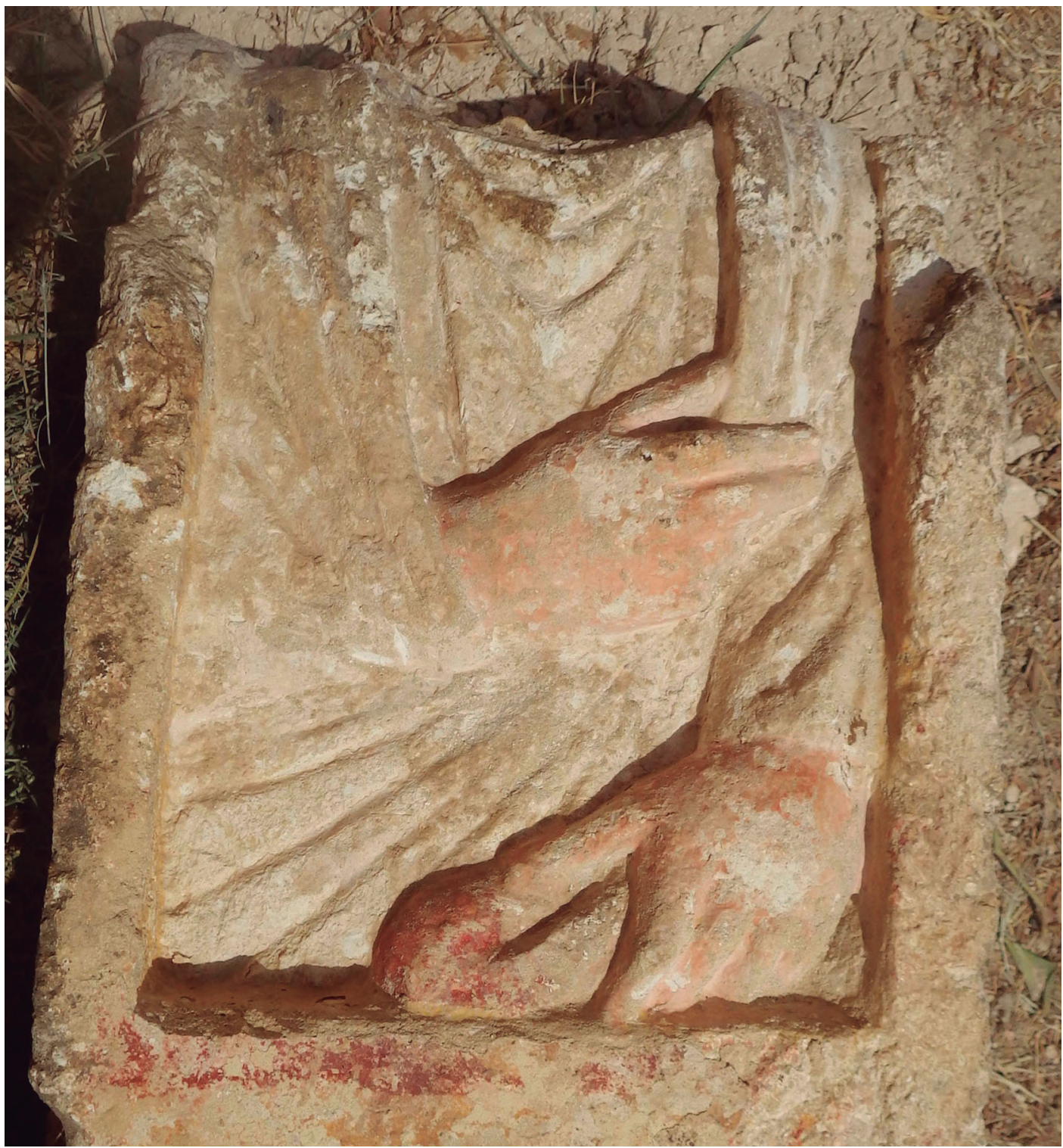

Figure 15. Stelae with the image of a male figure.

accompanied them is, unfortunately, impossible to determine.

In conclusion, although the syncretism between the Egyptian and Roman cultures is clearly reflected in the findings discovered in this necropolis, it is certain that subsequent excavations will provide new information about Egyptian funerary customs during the Roman Period.

\section{Bibliography}

Agustí, B.

2012 "Annex 2: Informe de l'anàlisi antropologic", Nilus 21: 17-23.

Burgaya, B.; XARriÉ, R.

2014 "Treballs de restauració realitzats a les pintures de la tomba $\mathrm{N}^{\circ}$ 3", in: J. Padró et Alii: La Tombe 
$\mathcal{N}^{\circ} 1$ à la Nécropole Haute. Oxyrhynchus III, (Nova Studia Aegyptiaca VIII), Barcelona: 213-215.

\section{Corcoran, L.}

1995 Portraits Mummies from Roman Egypt (I-IV centuries A.D.) with a Catalog of Portraits Mummies in Egyptian Museums. Chicago.

EgGebrecht, A.

1984 El Antiguo Egipto. 3000 años de historia y cultura del Imperio faraónico. Munich.

Erroux-Morfin, M.

2014 "Les peintures de la Tombe 3 à la Nécropole Haute", in: J. Padró et alii: La Tombe $\mathcal{N}^{o} 1$ à la Nécropole Haute. Oxyrhynchus III, (Nova Studia Aegyptiaca VIII), Barcelona: 199-212.

Kelley, A.

1976 The pottery of Ancient Egypt. Dynasty I to Roman times. London.

PADRó, J.

2009 "Trabajos de excavación realizados en el yacimiento arqueológico de Oxirrinco (El Bahnasa, Minia, Egipto) durante la campaña de 2009 (octubre-diciembre)", in: Informes y Trabajos 5. Excavaciones en el exterior 2009, (IPCE 5), Madrid: 36-45.

Padró, J.; Amer, H.I.; Castellano, N.; Erroux-Morfin, M.; Hamza, M.; Gonzálvez, L. M.; Marí, L.L.; Martínez, J.J.; Mascort, M.; Piedrafita, C.; Pons, E.; Subías, E.; Xarrié, $\mathrm{R}$.

2006 Oxyrhynchos I. Fouilles Archéologiques à El-Bahnasa (1982-2005). (Nova Studia Aegyptiaca III). Barcelona.

Padró, J.; Amer, H.I; Castellano, N.; Codina, D.; Erroux-Morfin, M.; Mangado, M.L.; Martínez, J.J.; Mascort, M.; Pons, E.; Saura, M.; Subías, E.

2008 "Memòria provisional dels treballs arqueològics realitzats al jaciment d'Oxirrinc (ElBahnasa, Minia), durant la campanya de 2008", Nilus 17: 3-16.

Padró, J.; Amer, H.I.; Castellano, N.; Codina, D.; Erroux-Morfin, M.; Mangado, M.L.;
Martínez, J.J.; Mascort, M.; Pons, E.; Subías, E.

2009 "Memòria provisional dels treballs arqueològics realitzats al jaciment d'Oxirrinc (ElBahnasa, Minia), durant la campanya de 2009", Nilus 18: 3-16.

Padró, J.; Agustí, B.; Amer, H.I.; Codina. D.; ErrouX-Morfin, M.; Martínez, J.J.; Mascort, M.; Pons, E.; Ruidavets, I.; Van Neer, W.

2013 "Informe preliminar dels treballs arqueològics realitzats a Oxirrinc (El-Bahnasa, Mínia, Egipte), durant la campanya de 2013", Nilus 22: 3-14.

Padró, J.; Agustí, B.; Amer, H.I.; Codina. D.; Erroux-Morfin, M.; González J.; Martínez, J.J.; Mascort, M.; Pons, E.; Ruidavets, I.; Van NeER, W.

2014 "Memòria preliminar del les excavacions de la campanya de 2014 a El-Bahnasa, Oxirrinc, (Minia, Egipte)", Nilus 23: 3-18.

Pons, E.

2012 "Archaeological Site of Oxyrhynchus (el Bahnasa), Egypt: Greco-Roman Tombs", in: G. Belova and S.V. Ivanov (ed.): Achievements and problems of modern Egyptology: Proceedings of the International Conference Held in Moscow on September 29-October 2, 2009, Moscow: 287-296.

2014 "Otras representaciones osiríacas en tumbas de época romana en el yacimiento arqueológico de Oxirrinco (El-Bahnasa)", in: J. Padró et Alii: La Tombe $\mathcal{N}^{o} 1$ à la Nécropole Haute. Oxyrhynchus III, (Nova Studia Aegyptiaca VIII), Barcelona: 287- 292.

WALKer, S.; Bierbrier, M.

1997 Fayum. Misteriosi volti dall'Egitto. London. 


\section{Trabajos de Egiptología}

Papers on Ancient Egypt 


\section{Consejo editorial}

\section{Director}

Miguel Ángel Molinero Polo

Universidad de La Laguna, Tenerife, Islas Canarias

\section{Secretaría de edición}

Lucía Díaz-Iglesias Llanos

Centro Superior de Investigaciones Científicas, Madrid

Alba María Villar Gómez

Universidad Autónoma de Madrid

\section{Colaborador de edición / English editorial assistant}

Kenneth Griffin

Swansea University, Gales, Reino Unido

\section{Consejo de redacción}

Antonio Pérez Largacha

Universidad de Castilla - La Mancha

José Ramón Pérez-Accino Picatoste

Universidad Complutense de Madrid

$\mathrm{M}^{\mathrm{a}}$ Covadonga Sevilla Cueva

Universidad Autónoma de Madrid

\section{Comité científico}

Josep Cervelló Autuori

Universitat Autònoma de Barcelona

María José López-Grande

Universidad Autónoma de Madrid

Josep Padró i Parcerisa

Universitat de Barcelona

M. ${ }^{a}$ Carmen Pérez Die

Museo Arqueológico Nacional, Madrid

Esther Pons Mellado

Museo Arqueológico Nacional, Madrid

José Miguel Serrano Delgado

Universidad de Sevilla 


\section{Trabajos de Egiptología}

Papers on Ancient Egypt

Número 7

2016 
Trabajos de Egiptología está producida por

Isfet. Egiptología e Historia

con la colaboración del Centro de Estudios Africanos

de la Universidad de La Laguna

C/ Blanco 1, $2^{\circ}$

38400 Puerto de la Cruz

Tenerife-Islas Canarias

España

(C) De los textos: sus autores y Trabajos de Egiptología

Diseño de arte y maquetación

Marian Montesdeoca y Ulises Ramos

info@marianmontesdeoca.com

Imprime: Gráfica Los Majuelos

Depósito Legal: TF 935-2015

ISSN: 1695-4750 


\section{Contents}

$\begin{array}{ll}\text { Prefacio/Foreword } & 7\end{array}$

Chiefs, Kings, and Patrons. Leadership and Social Logics in the Beginnings of Ancient Egypt 9 Marcelo CAMPAGNO

The Development of Local Osirian Forms. An Explanatory Model

Lucía DÍAZ-IGLESIAS LLANOS

Shaushka, the Traveling Goddess

Graciela GESTOSO SINGER

What are we Talking about when we Talk about Memphis?

Maria Helena Trindade LOPES

Stone Vessels of Egyptian Appearance from Ibiza

67

María José LÓPEZ-GRANDE

The Argentine Archaeological Mission at Tell el-Ghaba. A Third Intermediate-Early Saite Period Site on the Ancient Egyptian Eastern Border. Remarks and Main Results Silvia LUPO

TT 209. Objectives of the proyecto dos cero nueve and the Name of the Tomb Owner Miguel Ángel MOLINERO POLO

The Herakleopolis Magna Project (Ehnasya el Medina). Summary and Results of Work 2000-2015

M. ${ }^{a}$ Carmen PÉREZ DIE

Tombs of the Roman Period in Sector 26 of the High Necropolis Archaeological Site of Oxyrhynchus, El-Bahnasa

Esther PONS MELLADO

The Decoration of the Pronaos of Petosiris' Tomb. Themes, Scenes, Styles and Techniques José das Candeias SALES

The Artist in his Context: New Tendencies on the Research of Ancient Egyptian Art Inmaculada VIVAS SÁINZ 